\title{
Mitochondrial and nuclear markers reveal a lack of genetic structure in the entocommensal nemertean Malacobdella arrokeana in the Patagonian gulfs
}

\author{
José E. F. Alfaya · Gregorio Bigatti • \\ Annie Machordom
}

Received: 25 February 2012/Revised: 2 August 2012/Accepted: 4 August 2012/Published online: 24 August 2012

(C) Springer-Verlag and AWI 2012

\begin{abstract}
Malacobdella arrokeana is an entocommensal nemertean exclusively found in the bivalve geoduck Panopea abbreviata, and it is the only representative of the genus in the southern hemisphere. To characterize its genetic diversity, population structure and recent demographic history, we conducted the first genetic survey on this species, using sequence data for the cytochrome oxidase I gene (COI), 16S rRNA (16S) and the internal transcribed spacer (ITS2). Only four different ITS2 genotypes were found in the whole sample, and the two main haplotypes identified in the mitochondrial dataset were present among all localities with a diversity ranging from 0.583 to 0.939 . Nucleotide diversity was low $(\pi=0.001-0.002)$. No significant genetic structure was detected between populations, and mismatch distribution patterns and neutrality tests results are consistent with a population in expansion or under selection. Analysis of molecular variance (AMOVA) revealed that the largest level of variance observed was due to intrapopulation variation $(100,100$ and $94.39 \%$ for $16 \mathrm{~S}$, COI and ITS2, respectively). $F_{s t}$ values were also non-significant. The observed lack of population structure is likely due to high levels of genetic connectivity in combination with the lack or permeability of biogeographic barriers and episodes of habitat modification.
\end{abstract}

Communicated by M. Thiel.

J. E. F. Alfaya - G. Bigatti

LARBIM, Centro Nacional Patagónico (CENPAT-CONICET),

Bvd. Brown 2915, U9120ACV Puerto Madryn,

Chubut, Argentina

A. Machordom $(\bowtie)$

Museo Nacional de Ciencias Naturales (MNCN-CSIC),

José Gutiérrez Abascal, 2, 28006 Madrid, Spain

e-mail: annie@mncn.csic.es
Keywords Nemertean · Entocommensal - Geoduck · Genetic variation · Patagonia

\section{Introduction}

Few studies in nemertean biology have examined the genetic structure of nemertean populations (Sundberg and Strand 2007; Thornhill et al. 2008; Andrade et al. 2011). Here, we present the first genetic characterization of the genetic diversity, population structure and recent demographic history of the entocommensal nemertean Malacobdella arrokeana Ivanov et al. 2002. Members of the genus Malacobdella belong to the order Hoplonemertea. Shared characteristics include direct development and nonfeeding planuliform larvae (Maslakova and von Döhren 2009). Malacobdella arrokeana lives commensally within the mantle cavity of the bivalve geoduck Panopea abbreviata Valenciennes, 1839 and is the only species of the genus reported in the southern Atlantic Ocean (Ivanov et al. 2002). It attaches to host mantle tissues by means of its terminal sucker. In general, each bivalve hosts a single mature nemertean. Teso et al. (2006) and Vázquez et al. (2009) reported that from 99.4 to $100 \%(n=762$ geoducks in total from the two studies) of $P$. abbreviata were inhabited by at least one specimen of $M$. arrokeana (with a maximum of 191 specimens in one clam). Populations of M. arrokeana and its host, $P$. abbreviata (also an endemic species of the South Atlantic Ocean), are abundant in the northern Patagonian gulfs; they live in aggregations, buried deeply (up to $40 \mathrm{~cm}$ in depth) in sand and mud substrata (Morsan et al. 2010 and references therein). The northern Patagonian San Matías, San José and Nuevo gulfs (Fig. 1A) occur at the limit of the Magellanic and 


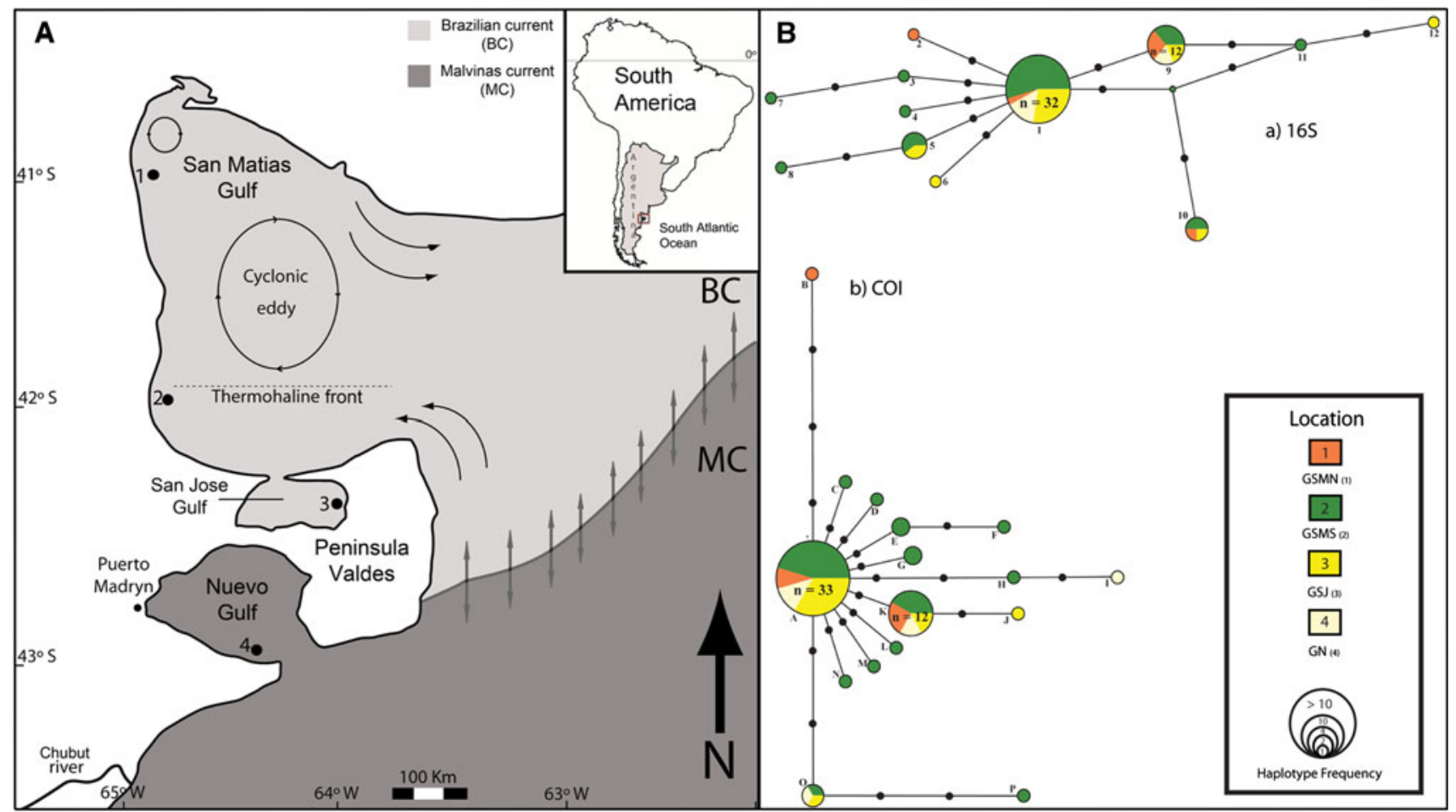

Fig. 1 A Southern Atlantic Ocean populations of the geoduck Panopea abbreviata were collected from: 1 El Sótano (northwest coast of San Matías gulf), 2 Puerto Lobos (southwest coast of San Matías gulf), 3 Punta Conos (San José gulf) and 4 Bahía Craker (Nuevo gulf). In all areas, samples were collected at depths between 5 and $25 \mathrm{~m}$. B Networks of North Patagonian gulf populations of Malacobdella arrokeana analyzed, using $95 \%$ connectivity level. a Network based on 16S mtDNA. b Network based on COI mtDNA. Alphanumeric names (designated by letters corresponding to COI

Argentinian biogeographic provinces. Each of these provinces has different oceanographic conditions (Scarabino 1977, Boschi 2000). The latitudinal thermal gradient in this area is controlled by the shallow and cold Malvinas current that flows northwards and by the warm Brazilian current that flows southwards (Martínez and del Río 2002). Peninsula Valdes is considered the confluence zone and a natural barrier. However, some taxa are represented in both provinces (Boschi 2000); this is the case for M. arrokeana and its host.

Previous studies on other marine invertebrates showed differences among Patagonian gulf populations. For example, Real et al. (2004) reported genetic variation between northern and southern San Matías populations of the scallop Aequipecten tehuelchus, estimating that genetic distances were higher between San Matías populations than between these populations and San José gulf population. Panopea abbreviata specimens from different populations of the San Matías gulf indicate different rates of individual growth between populations located on either side of the thermohaline front (Morsan et al. 2010). Considering the sequences and numbers corresponding to $16 \mathrm{~S}$ sequences) are provided for each haplotype. Sampled haplotypes are indicated by colored circles, according to the geographical region from which the sample was collected as in $\mathbf{A}$; missing or unsampled haplotypes are indicated by black dots. Each branch indicates a single mutational difference. Circle size is proportional to observed haplotype frequency; observed number of ancestral haplotypes is indicated by " $n=$ " (the number of times each haplotype was obtained). GSMN northern San Matías gulf, GSMS southern San Matías gulf, GSJ San José gulf, GN Nuevo gulf

supposedly limited larval dispersal capacity of M. arrokeana, its strict association with a sessile bivalve and the particularities of its habitats (in gulfs isolated due to different causes), a certain level of genetic structure among $M$. arrokeana populations is expected.

\section{Materials and methods}

\section{Sampling}

Malacobdella arrokeana specimens were sampled in an area that covers the entire Argentinian P. abbreviata distribution sensu Scarabino (1977), from Mar del Plata (800 km North of GSM, coast of Argentina $38^{\circ} \mathrm{S}$ ) to Puerto Deseado $(550 \mathrm{~km}$ south of the Nuevo gulf) at depths ranging from 15 to $20 \mathrm{~m}$. Specimens were only found in three northern Patagonic gulfs: San Matías-north, El Sótano (GSMN, $n=7$ ), and San Matías-south, Puerto Lobos (GSMS, $n=35$ ); San José (GSJ, $n=17$ ) and Nuevo (GN, $n=8$ ) (Fig. 1A). The clams were collected by SCUBA 
diving, using a hydro-jet to dislodge them from the substratum.

Clams were transported isolated in plastic bags and opened in the laboratory by severing both anterior and posterior adductor muscles. All of the M. arrokeana inside each clam were removed alive using a scalpel, and immediately fixed in absolute ethanol. The low numbers of samples from the GSMN and GN populations were due to low $P$. abbreviata population densities at greater depths (25-30 m).

DNA extraction, PCR amplification, and sequencing

Nemertean (and voucher geoducks) specimens were stored in absolute ethanol. DNA was extracted from preserved tissue using the DNeasy extraction Kit (Qiagen, Inc.) according to the manufacturer's protocol. Partial nemertean COI, 16S and ITS2 sequences were amplified by PCR using the following primers: 16sar-L and 16sbr-H (Palumbi et al. 1991) for 16S; LCO1490 (Folmer et al. 1994) and COI-H (Machordom et al. 2003) for COI and ITS2-3d (White et al. 1990) and ITS2-4r (5'-AGT TTY TTT TCC TCC GCT TA-3') (modified from White et al. 1990) for ITS2. Amplifications were carried out in a $50 \mu \mathrm{l}$ of final volume reaction containing $5 \mu \mathrm{l}$ of $10 \times$ buffer (containing $\left.10 \times 2 \mathrm{mM} \mathrm{MgCl}_{2}\right), 1 \mu \mathrm{l}$ dNTPs mix $(10 \mathrm{mM}), 0.8 \mu \mathrm{l}$ of each primer $(10 \mu \mathrm{M}), 0.4 \mu \mathrm{l}$ of Taq DNA polymerase $(5 \mathrm{U} / \mu \mathrm{l})$ (Biotools) and 1-3 $\mu \mathrm{l}$ of genomic DNA. Thermocycling for the COI fragment included an initial 4 min denaturation step at $94{ }^{\circ} \mathrm{C}$, followed by 40 cycles of $45 \mathrm{~s}$ at $94{ }^{\circ} \mathrm{C}$, $1 \mathrm{~min}$ at $46.5^{\circ} \mathrm{C}$ and $1 \mathrm{~min}$ at $72{ }^{\circ} \mathrm{C}$. The cycle ended with $10 \mathrm{~min}$ of sequence extension at $72{ }^{\circ} \mathrm{C}$. For $16 \mathrm{~S}$ and ITS2, we used the same cycle parameters, but annealing temperatures were 42 and $47^{\circ} \mathrm{C}$, respectively. Products were visualized under blue light in $0.8 \%$ agarose gels stained with SYBR Safe (Invitrogen), with co-migrating 100 bp or $1 \mathrm{~Kb}$ ladder molecular weight markers. The amplification products (approximately $700 \mathrm{bp}$ for each gene) were purified by ethanol precipitation. Sequencing of selected fragments was performed for both strands in an automatic ABI 3730 sequencer (Applied Biosystems Inc.) using BigDye Terminator kits.

Approximately 1900 base pairs were sequenced for M. arrokeana (658 bp for the mitochondrial COI, $533 \mathrm{bp}$ for $16 \mathrm{~S}$ and approximately $700 \mathrm{bp}$ for the nuclear ITS2) (GenBank accession numbers JX220535-JX220725).

\section{Data analysis}

Sequences of each sample analyzed were refined by strand comparison, and primers sequences cut using the Sequencher program (Gene Code Corporation) and aligned using Se-Al 2.0a11 (Rambaut 2002). Haplotype networks analyses were performed using TCS 1.18 (Clement et al. 2000) and Network 4.5 (www.fluxus-engineering.com), with default parameters, $95 \%$ limit connection and gaps considered as either a fifth character state or as missing data. Only the $16 \mathrm{~S}$ data set presented a reticulation.

For each fragment, and when appropriate for a concatenated matrix of COI, 16S and ITS2 data, genetic parameters of differentiation (e.g., number of haplotypes, haplotype and nucleotide diversities, F-statistics, AMOVA [considering each locality separately and also grouped by gulf], mismatch distribution, Tajima's $D$, Fu's $F_{s}$ tests of neutrality) were obtained using the following software: Arlequin 3.5 (Excoffier and Lischer 2010) and DnaSP 5.0 (Librado and Rozas 2009).

To test the hypothesis of correlation between genetic and geographic distance, we performed 1000 randomizations of a Mantel test using the program IBDWS (Jensen et al. 2005) and the $F_{s t}$ and linearized $F_{s t}\left(\right.$ i.e., $\left.F_{s t} /\left(1-F_{s t}\right)\right)$ against the logarithm of geographic distance. Demographic population history was inferred by comparing mismatch distributions of pairwise nucleotide differences among haplotypes of each gene, both separately and combined, using Arlequin 3.5.

\section{Results}

Specimens of $P$. abbreviata were only found from the San Matías gulf to the Nuevo gulf, and no evidence of living or empty shells was reported south of the Nuevo gulf. All but 3 of the geoducks ( 2 from GSMS and 1 from GSJ) sampled contained a single adult specimen of M. arrokeana. The two mentioned clams from GSMS hosted 3 and 6, and the clam from GSJ 7 immature nemerteans, respectively, but no mature ones.

Sixteen exclusive haplotypes were found for COI, twelve for 16S and four for ITS2. The two most frequent haplotypes observed for COI and 16S (found in 33 and 12 specimens for COI and 32 and 12 for $16 \mathrm{~S}$ ) were shared among all localities. Haplotype diversity (Hd) was relatively high, ranging from 0.583 to 0.939 (Table 1). The different networks for each gene or for the matrix that included the 3 gene regions (Fig. 1B, ITS2 not shown) revealed a high number of rare haplotypes, differing primarily by a single mutational step with the most frequent haplotype/genotype. Therefore, low nucleotide diversity $(\pi)$ of $0.001-0.002$ was observed (Table 1). The majority of the rare haplotypes belonged to the immature specimens, which did not have the most frequent haplotypes (these were only found in mature specimens).

There was almost no genetic differentiation among populations: AMOVA, either examining each population separately or grouped by gulfs, revealed that most of the 
Table 1 Genetic population parameters recorded for M. arrokeana in the four different populations

\begin{tabular}{|c|c|c|c|c|c|c|c|c|c|c|}
\hline & \multicolumn{5}{|c|}{$16 \mathrm{~S}$} & \multicolumn{5}{|l|}{ COI } \\
\hline & $n$ & $\mathrm{Hd}$ & $\pi$ & Fu's & Ta'D & $n$ & $\mathrm{Hd}$ & $\pi$ & Fu's & Ta'D \\
\hline GSMN & 5 & 0.700 & 0.002 & -0.475 & 0.243 & 7 & 0.714 & 0.001 & -0.237 & 0.206 \\
\hline GSMS & 32 & 0.671 & 0.002 & $-4.163^{*}$ & -1.362 & 32 & 0.778 & 0.002 & $-9.171 * * *$ & $-2.058^{*}$ \\
\hline GSJ & 16 & 0.683 & 0.002 & -3.011 & -0.793 & 15 & 0.447 & 0.001 & -0.064 & -1.009 \\
\hline GN & 8 & 0.607 & 0.001 & -0.478 & -0.448 & 8 & 0.750 & 0.002 & -0.197 & -1.280 \\
\hline \multirow[t]{3}{*}{ TOTAL } & 61 & 0.673 & 0.002 & $-6.973 * * *$ & -1.436 & 63 & 0.687 & 0.002 & $-10.960 * * *$ & $-2.034 *$ \\
\hline & \multicolumn{5}{|c|}{ ITS-2 } & \multicolumn{5}{|c|}{3 MARKERS } \\
\hline & $n$ & $\mathrm{Hd}$ & $\pi$ & Fu's & Ta'D & $n$ & Hd & $\pi$ & Fu's & Ta’D \\
\hline GSMN & 7 & 0.809 & 0.001 & -1.390 & -0.654 & 5 & 1.000 & 0.001 & -2.371 & -0.190 \\
\hline GSMS & 35 & 0.569 & 0.001 & -1.576 & -0.793 & 30 & 0.954 & 0.001 & -11.974 & -1.867 \\
\hline GSJ & 17 & 0.323 & 0.000 & -1.038 & -1.069 & 13 & 0.871 & 0.001 & -5.391 & -0.945 \\
\hline GN & 8 & 0.750 & 0.001 & -1.096 & -0.304 & 8 & 0.964 & 0.001 & -2.870 & -0.958 \\
\hline TOTAL & 67 & 0.583 & 0.001 & -0.893 & -0.387 & 56 & 0.939 & 0.001 & -26.19 & -1.727 \\
\hline
\end{tabular}

GSMN and GSMS northern and southern populations of the San Matías gulf, GSJ San José gulf, GN Nuevo gulf, $n$ number of samples, $H d$ haplotype diversity, $\pi$ nucleotide diversity, Fu's and Ta'D represent the values obtained in Fu's $F s$ and Tajima's $D$ tests, respectively. $* p<0.05 ; * * * p<0.001$

observed variance was due to intrapopulation variation (100, 100, and $94.39 \%$ for $16 \mathrm{~S}$, COI, and ITS2, respectively). $F_{s t}$ values for the four populations were negative for both of the mitochondrial genes and not statistically significant. Since the range for $F_{s t}$ values is $0-1$, but due to software limitations, negative values are sometimes provided for very small $F_{s t}$ values, such figures should be considered zero (Long 1986), indicating no differentiation among populations. For ITS2, $F_{s t}$ was 0.056 , which was also not significant $(p=0.067)$. Mantel tests showed no relationships between the different $F_{s t}$ values $(Z=0.0059$, $r=-0.1583, p=0.62$ ) or the linearized $F_{s t}$ values $(Z=0.0132, r=-0.1611, p=0.64)$, with respect to geographic distances.

Mismatch distributions for each gene and population, and for combined matrices showed the same expansion/selection model profile, except for COI sequences from Nuevo gulf specimens, which resulted in a bimodal curve. In addition, Fu's $F s$ and Tajima's $D$ values were mainly negative (Table 1 ) and significant when the number of specimens analyzed was sufficiently large for both mitochondrial markers. Considering all of the populations together, Fu's $F s$ and Tajima's $D$ values were both significant only for COI, and Fu's Fs was only significant for $16 \mathrm{~S}$. Although both parameters were also negative for ITS2, no significance was detected.

\section{Discussion}

No $P$. abbreviata populations were found outside of the Patagonian gulfs, and $M$. arrokeana was never found outside of its host or in other bivalves. The difficulty in host sampling (as animals are deeply buried in the sediment) makes extraction by trawling impossible, and the low visibility in waters outside the northern Patagonian gulfs makes manual extraction difficult. Furthermore, north of the Patagonian gulfs, $P$. abbreviata lives in deeper waters (at depths of 70-200 m) (F. Scarabino, personal communication). The low density observed in Nuevo gulf might denote the distribution limit of $P$. abbreviata.

In our study, a lack of genetic differentiation was observed among populations living in the different gulfs. This result is consistent with previous studies in nemertean genetic populations. Rogers et al. (1997) found evidence of low genetic differentiation in populations of two different free-living nemertean species, which are separated by large geographic distances (thousands of $\mathrm{km}$ ). Thornhill et al. (2008) and Sundberg and Strand (2007), using partial COI and $16 \mathrm{~S}$ gene sequences, also detected a homogeneous genetic structure in populations of the heteronemertean Parborlasia corrugatus from South America and of Riseriellus occulatus from Spain and Wales, respectively. Thornhill et al. (2008) only observed genetic structure on either side of Drake Passage, a strong barrier to gene flow.

Several aspects of nearshore oceanographic conditions in the Patagonian gulfs are consistent with the geographical patterns in gene flow observed in this study. Along the Patagonian coast, the tidal range is among the highest in the world, generating strong currents and significant variations in sea level (Palma et al. 2004). The shelf water of the Malvinas current enters from south of the San Matías gulf, determining a water residence time in the San Matías 
gulf of approximately 300 days (Rivas and Beier 1990). Low levels of genetic differentiation related to larval retention and oceanographic conditions were previously shown in many invertebrate species populations along the Pacific coast (Sotka et al. 2004; Kelly and Palumbi 2010). Besides, the Argentinean coasts suffered several glacial periods (following the Pleistocene, as well as in the Late Miocene and Holocene) that resulted in changes in sea level, salinity and temperature (Martínez and del Río 2002). Due to such changes, new available niches might have led to the rapid expansion of cold-water species, such as $P$. abbreviata and therefore to its closely associated entocommensal, $M$. arrokeana. Population expansion from restricted areas into newly available habitats from marine refugia could explain the loss of genetic structure of nearshore fishes and invertebrates (Sotka et al. 2004 and references therein).

Interestingly, only one mature $M$. arrokeana is usually found inside a single geoduck. When more than one $M$. arrokeana were found inside a single $P$. abbreviata, those nemerteans were immature (Ivanov et al. 2002; Teso et al. 2006; Vázquez et al. 2009; this study). This finding indicates an exclusion process during maturation of the nemertean, likely due to intraspecific competition for space (see Bush and Lotz 2000), chemical inhibition of maturation between individuals (Teso et al. 2006), or both. Our results showed that the three cases in which more than one nemertean was found per geoduck, the corresponding specimens presented a proportionately larger number of rare haplotypes (maturecommon, immature-rare). Although based on the low numbers of immature specimens examined here, we wonder whether, in addition to the factors mentioned above, a selection of common haplotypes could be acting on these populations. Future research efforts, such as analyzing more cases of multiple specimens in a single clam in combination with the analysis of highly variable markers (e.g., microsatellites), will help shed light on the potential selection pressures affecting populations of M. arrokeana.

Acknowledgments The authors thank Ricardo Vera, Miguel Ángel Díaz, Néstor Ortiz, Pilar Casado de Amezúa, Iván Acevedo and Ricardo García-Jiménez for providing samples and technical support, and David Buckley, Patricia Cabezas, three anonymous reviewers and Martin Thiel for their valuable comments. Ana Burton and Melinda Modrell revised the English. This study was financially supported by grants from the Fundación BBVA (Conservation Biology program), the Lerner-Gray Fund for Marine Research (AMNH), Ministerio de Educación de la provincial de Chubut and the Agencia Española de Cooperación Internacional y Desarrollo (AECID: A/023484/09 and A/032441/10).

\section{References}

Andrade SCS, Norenburg JL, Solferini VN (2011) Worms without borders: genetic diversity patterns in four Brazilian
Ototyphlonemertes species (Nemertea, Hoplonemertea). Mar Biol 158:2109-2124

Boschi E (2000) Species of decapod crustaceans and their distribution in the American marine zoogeographic provinces. Rev Investig Desarrollo Pesquero 13:7-136

Bush AO, Lotz JM (2000) The ecology of "crowding". J Parasitol 86:212-213

Clement M, Posada D, Crandall K (2000) TCS: a computer program to estimate gene genealogies. Mol Ecol 9:1657-1660

Excoffier L, Lischer HEL (2010) Arlequin suite ver 3.5: a new series of programs to perform population genetics analyses under Linux and Windows. Mol Ecol Resour 10:564-567

Folmer O, Black M, Hoeh W, Lutz R, Vrijenhoek R (1994) DNA primers for amplification of mitochondrial cytochrome $c$ oxidase subunit I from diverse metazoan invertebrates. Mol Mar Biol Biotech 3:294-299

Ivanov VA, Bigatti G, Penchaszadeh PE, Norenburg JL (2002) Malacobdella arrokeana (Nemertea: Bdellonemertea), a new species of nemertean from the Southwestern Atlantic Ocean entocommensal in Panopea abbreviata (Bivalvia, Heterodonta, Hiatellidae) in Argentina. Proc Biol Soc Wash 115:359-367

Jensen JL, Bohonak AJ, and Kelley ST (2005) Isolation by distance, web service. BMC Genetics 6:13. v.3.23. http://ibdws.sdsu.edu/

Kelly RP, Palumbi SR (2010) Genetic structure among 50 species of the Northeastern Pacific rocky intertidal community. PLoS ONE 5(1):e8594

Librado P, Rozas J (2009) DnaSP v5: a software for comprehensive analysis of DNA polymorphism data. Bioinformatics 25:1451-1452

Long JC (1986) The allelic correlation structure of Gainj- and Kalamspeaking people. I. The estimation and interpretation of Wright's F-statistics. Genetics 112:629-647

Machordom A, Araujo R, Erpenbeck D, Ramos MA (2003) Phylogeography and conservation genetics of endangered European Margaritiferidae (Bivalvia: Unionoidea). Biol J Linn Soc 78: 235-252

Martínez S, del Río CJ (2002) Late Miocene molluscs from the southwestern Atlantic Ocean (Argentina and Uruguay): a palaeobiogeographic analysis. Palaeogeogr Palaeoecl 188:167-187

Maslakova SA, von Döhren J (2009) Larval development with transitory epidermis in Paranemertes peregrina and other hoplonemerteans. Biol Bull 216:273-292

Morsan E, Zaidman P, Ocampo-Reinaldo M, Ciocco N (2010) Population structure, distribution and harvesting of southern geoduck, Panopea abbreviata, in San Matías Gulf (Patagonia, Argentina). Sci Mar 74:763-772

Palma ED, Matano RP, Piola R (2004) A numerical study of the Southwest Atlantic Shelf Circulation: Barotropic response to tidal and wind forcing. J Geophys Res 109:CO8014

Palumbi S, Martin A, Romano S, McMillian WO, Stice L, Grabowski G (1991) The simple fool's guide to PCR. University of Hawaii, Honolulu

Rambaut A (2002) Se-Al v. 2.0a11: sequence alignment program. http://tree.bio.ed.ac.uk/software/seal/

Real LE, Julio N, Gardenal NC, Ciocco NF (2004) Genetic variability of Tehuelche scallop, Aequipecten tehuelchus populations from the Patagonian coasts (Argentina). J Mar Biol Assoc UK 84: 235-238

Rivas AL, Beier EJ (1990) Temperature and salinity fields in the northpatagonic Gulfs. Oceanol Acta 13:15-20

Rogers AD, Thorpe JP, Gibson R, Norenburg JL (1997) Genetic differentiation of populations of the common intertidal nemerteans Lineus ruber and Lineus viridis (Nemertea, Anopla). Hydrobiologia 365:1-11

Scarabino V (1977) Moluscos del Golfo San Matías (Provincia de Río Negro, República Argentina). Inventario y claves para su identificación. CSMU 4:177-285 
Sotka EE, Wares JP, Barth JA, Grosberg RK, Palumbi SR (2004) Strong genetic clines and geographical variation in gene flow in the rocky intertidal barnacle Balanus glandula. Mol Ecol 13: 2143-2156

Sundberg P, Strand M (2007) Genetics do not reflect habitat differences in Riseriellus occultus (Heteronemertea, Nemertea) from Spain and Wales. Mar Biol Res 3:117-122

Teso SV, Bigatti G, Bazterrica MC, Ciocco NF, Penchaszadeh PE (2006) The reproductive cycle of the entocommensal nemertean Malacobdella arrokeana and its symbiosis with the geoduck Panopea abbreviata. Invertebr Biol 125:314-324

Thornhill DJ, Mahon AR, Norenburg JL, Halanych KM (2008) Openocean barriers to dispersal: a test case with the Antarctic Polar front and the ribbon worm Parborlasia corrugatus (Nemertea: Lineidae). Mol Ecol 17:5104-5117

Vázquez N, Bigatti G, Ituarte C, Cremonte F (2009) Attachment of the nemertean Malacobdella arrokeana to mantle tissues of the geoduck Panopea abbreviata and survival outside the host. J Shellfish Res 28:759-761

White TJ, Bruns T, Lee S, Taylor JW (1990) Amplification and direct sequencing of fungal ribosomal RNA genes for phylogenetics. In: Innis MA, Gelfand DH, Sninsky JJ, White TJ (eds) PCR protocols: a guide to methods and applications. Academic Press Inc, New York, pp 315-322 